\title{
岡山大学大学院自然科学研究科 生体統御学グループ
}

御輿 真穂 (岡山大学大学院 自然科学研究科・助教) E-mail: ogoshi-m@cc.okayama-u.ac.jp

\section{1. 岡山大学ってどんなところ ?}

降水量が少なく、「晴れの国」として知られる岡山県。 岡山大学は、岡山駅からほど近いところに2つのキャン パスを構え、他にも県内の様々なエリアに研究施設をも つ総合大学です。メインキャンパスである津島キャンパ スは、理・薬・工・農・環境理工・教育・文・法・経済 の各学部を擁し、農場を含めた広大な敷地をもつていま す。新幹線の止まる駅から自転車で行ける距離にこれだ けの規模の大学というのは、昨今珍しくなりつつあるの ではないでしょうか。市街地が平坦で走りやすいことも あって、大学関係者の自転車利用率は高く、1限開始前 の大学周辺は自転車の海のようになります。しかし一方 で、用水路が多いことでも知られる岡山。油断は禁物で す。

\section{2. 研究室について}

2016年現在、私たちの研究室は4名の教員 (高橋純夫 教授、竹内栄教授、御舆、相澤清香助教) が集まった研 究グループという形をとつています。教員は各々独立し たテーマに取り組んでいますが、大きく分けて、高橋教 授率いる内分泌研究室 (通称ネズミ組) と竹内教授率い る生体情報システム研究室 (通称トリ班 : なぜ組に対し て班なのかは不明) がそれぞれに週 1 回のプログレス報 告会を行っており、14名の学生はそのどちらかに所属 して実験の進渉を報告します。さらに研究グループ全体 のセミナーも週 1 回あるため、自分の研究内容を話す機 会は自然に多くなり、そのことが学会発表などの場で活 きてくることになります。また、本学生物学科では学部 3 年生の 10 月から卒業研究を見据えて研究室に仮配属と なります。この原稿を書いている時点で数名の3年生が
所属し、実験技術を上級生に教わつたり、研究室セミナ ーで論文紹介を行ったりと活発に活動しています。

日々の研究以外でも研究グループの結束は強く、毎年 恒例のイベントとして春には花見、秋には遠足を行って います (写真1)。また、今年は学生たちが有志で大学祭 に「メダカすくい」の模擬店を出し、好評を博しました。 生き物の世話が必須となる当研究室は集まる学生たち も動物好きが多いようです。それから何故か女性が多く、 教員の女性比率を反映したわけでもなく常にそうなので すが、いずれにせよ賑やかな研究室です。

\section{3. 研究内容}

当研究グループは4名の教員が在籍し、研究テーマも 多岐にわたつているため、そのうちのいくつかを紹介し ます。共通するキーワードは、ホルモンや成長因子など の生理活性物質の脊椎動物における役割の解析です。

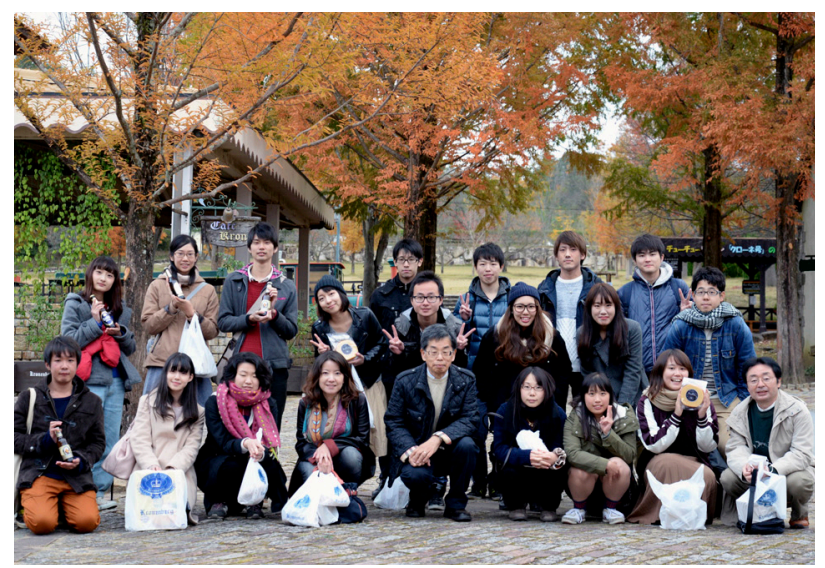

写真1 研究室イベント・秋の遠足の様子

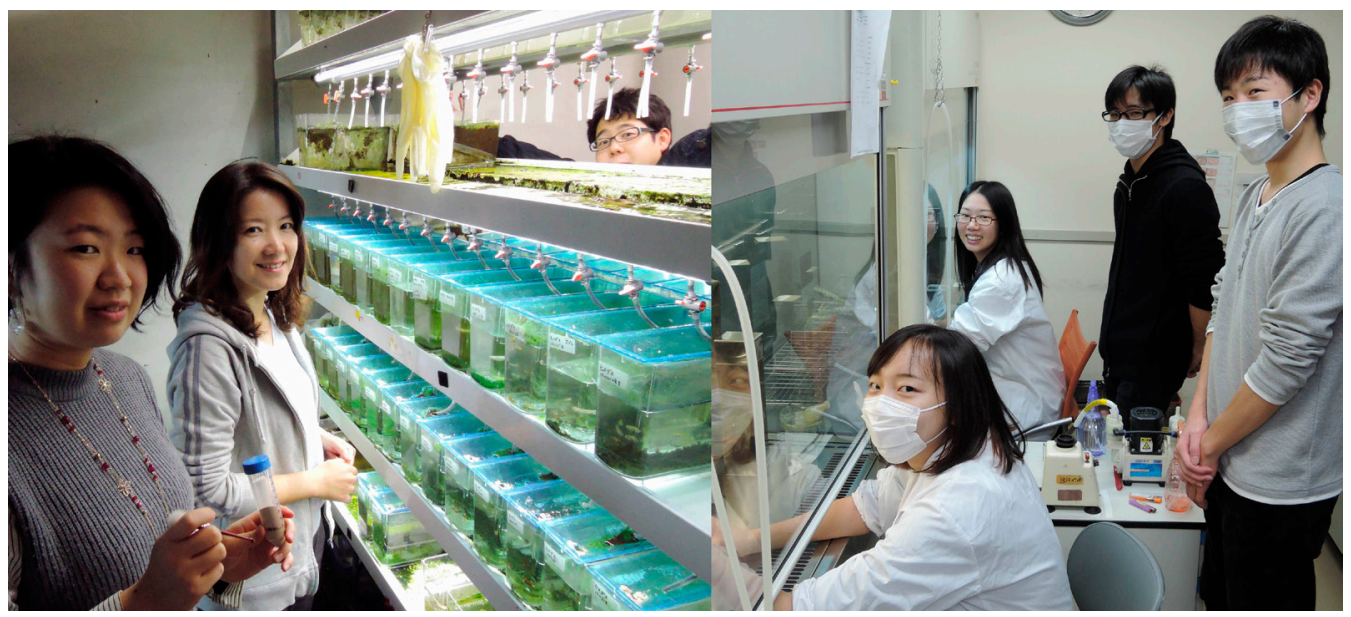

写真2 飼育室および実験室 (高橋純夫先生撮影) 
1 ）下垂体細胞の増殖と機能発現

生体調節機構の要となる下垂体における、ホルモン分 泌細胞の分化と増殖機構を解析しています。下垂体で合 成される成長因子のいくつかが、下垂体のホルモン産生 細胞の分化や増殖に関与していることを明らかにしまし た。さらに、下垂体ホルモンの合成や分泌がどのように 調節されているかも解析しています。

2 ) 子宮内膜および卵巣の機能発現

卵巣から分泌される性ホルモンは周期的にその量が変 動し、それに応じて子宮内膜の細胞が劇的に変化するこ とはよく知られています。私たちは、子宮で合成される 成長因子が、性ホルモンを助けて、子宮細胞の増殖調節 に重要な役割を果たしていることを明らかにしてきまし た。マウス子宮内膜の培養細胞系を用いて、成長因子と 性ステロイドホルモンによる制御機構のクロストークに 注目して解析を進めています。

3 ）鳥類の羽色調節と羽構造の形成機構

鳥類の雄は雌よりも鮮やかな色の羽をもつことはよく 知られていますが、羽色だけでなく羽の構造にも雌雄差 があります。このような色と構造を制御するホルモン系 について、主にメラノコルチン調節系関連遺伝子に注目 して解析しています。雌雄の羽に発現する遺伝子の比較 から、調節に関わる新たな遺伝子も同定し、その機能に ついても解析を進めています。
4 ）魚類から発見したホルモンの機能 生体恒常性の維 持機構

魚類の浸透圧調節機構を調べる過程で発見した、アド レノメデュリン (AM) 2およびAM5というホルモンの 機能を解析しています。哺乳類の多くの種で保存されて いるにもかかわらず、ヒトやマウスではAM5が欠損し ています。私たちはそのAM5について、魚類と両生類 を用い、血球の分化と免疫調節への関与に注目して解析 を進めています。

5 ）下垂体隆起部の生理的役割 生物リズムの形成

生物は光周期による自律的なリズムをもつことが知ら れています。下垂体隆起部には光周期に応じて増減する メラトニンの受容体が存在しますが、この部分がどのよ うに生物リズムに関わるかはわかっていません。隆起部 に発現するホルモンに注目し、摂食や代謝、睡眠などの 行動への関与について解析しています。

このように私たちは、魚類から哺乳類まで、脊椎動物 のほぼ全ての系統群に属する動物を扱い、分子生物学か ら行動解析に至るまで幅広い手法を用いて研究を行って います。研究グループの詳細については、ホームページ (http://www.biol.okayama-u.ac.jp/cccrg/) にも揭載して います。興味を持たれた方は是非ご連絡ください。楽し く充実した研究の日々を一緒に送りましょう。

\section{九州大学大学院農学研究院 海洋生物学研究分野}

大賀 浩史 (九州大学大学院 農学研究院 海洋生物学研究分野) E-mail: hohga@agr.kyushu-u.ac.jp

九州大学・海洋生物学講座です。九州大学農学部は福 岡市東区の箱崎キャンパスにあります。福岡市は人口 150 万人を超える大都市ですが、都市機能がコンパクト にまとまっており、北に玄界灘、南に背振山地と自然も 豊かで大変住みやすい街です。明太子、ラーメン、もつ 鍋や水炊き、そして玄界灘で水揚げされる新鮮な魚介類 などグルメの宝庫でもあります。箱崎キャンパスは福岡 空港やJR博多駅からも近く、福岡の繁華街である天神 や歓楽街の中洲にも地下鉄を使えば 10 分程度でアクセ スすることができます。九州大学は現在、福岡県糸島市 にある伊都キャンパスに移転中であり、農学部は 2 年後 の移転となります。

当研究室は水産科学コースの教室です。松山倫也教授、 太田耕平准教授、山口明彦助教、そして学術研究員であ る筆者というスタッフのもと、現在、博士学生 1 名、修 士学生 5 名、学部生 4 名と外国人研究生 1 名が学んでい ます (写真 1)。「魚類の性と生殖」を生理および生態の両 側面から解明し、成果を社会に還元することを目的とし て研究を行っています。研究テーマは遺伝子・分子レベ ルから個体群レベルまでと幅広いのですが、以下に主な ものをいくつかご紹介します。

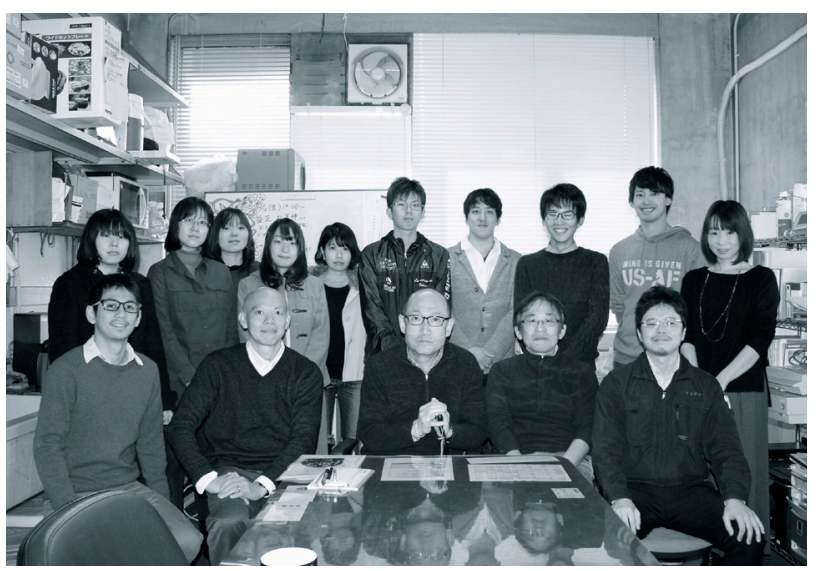

写真1 本年度の研究室メンバー

松山教授を前列中央に、左が太田准教授、右が山口助教、右 端が筆者。研究室のお茶室にて1枚。

\section{1. 魚類の性決定と性転換機構}

性転換は一部の例外を除き魚類のみに特有の現象です が、その生理・分子機構の詳細は明らかではありません。 採集がしやすく取り扱いの容易な雌性先熟魚であるホシ ササノハベラを用いて、主に内分泌学的観点より性転換 